\title{
ECOLOGICAL AND BIOLOGICAL STUDIES ON THE PREDATOR Clitostethus arcuatus (ROSSI) (COLEOPTERA: COCCINELLIDAE) AS A PREDATOR OF POMEGRANATE WHITELY, Siphoninus phillyreae (HOLIDAY) (HOMOPTERA: ALERODIDAE) \\ Awadalla, S. S. ${ }^{1}$; Hala A. El-Syrafi ${ }^{1}$; M. E. El-Naggar ${ }^{2}$ and Amany A. Khalifa ${ }^{2}$ \\ ${ }^{1}$ Economic Entomology Dept, Faculty of Agriculture, Mansoura Univ. \\ ${ }^{2}$ Plant Protection Res. Institute, Agric. Research Center, Dokki, Giza
}

\begin{abstract}
The present work was carried out to study the population abundance, biology and efficiency of the coccinellid predator Clitostethus arcuatus (Rossi) when fed on pomegranate-whitefly, Siphoninus phillyreae (Haliday) at Kafr El-Sheikh region during two successive seasons 2006 and 2007. S. phillyreae and its related predator $C$. arcuatus appeared together during May to June. The period from August through October considerable of the pest and its related predator $C$. arcuatus. Duration of the first, second, third, fourth larval instars and prepupae of the predator averaged were $1.2,2.2,2.6,2.8$ and 1.1 days, respectively. The total larval period, pupal stage at total developmental period averaged 3.6, 9.9 and 17.8 days, respectively. Adults, male and female averaged 69.2 and 103.1days, respectively. C. arcuatus larval consumed an average total number of 319.8 eggs. The adults male and female consumed an average number of 4237.6 and 5486.6 of $S$. phillyreae eggs, respectively.
\end{abstract}

Keywords: Clitostethus arcuatus, Siphoninus phillyreae, population, abundance, biology, efficiency.

\section{INTRODUCTION}

Clitostettius arcuatus (Rossi), a predator of aleyrodids and other insects and mites is one of several coccinellids predator to feed on whiteflies (Gerling, 1990). Its was widely distribution in the Mediterranean and surrounding areas, and France; the Italian peninsula (Priore, 1969, Loi, 1978); Sicily (Liotta, 1981); Greece (Mentzelos, 1967); Turkey (Soylu, 1980 and Ulu, 1985); Germany (Bathon and Bietrizik, 1986); the southern and western of former USSR (Agekyan, 1977). Its distribution in northern Africa was also considered (Agekyan, 1977). It feed on whiteflies eggs, nymphs and adults (Priore, 1969, Bathon and Pietrizik, 1986), with predation apparently primarily on the eggs and nymphs when all stages are present (Priore, 1969).

In the Summer 1989, C. arcuatus (Rossi) was imported from Israel to California as a part of a broader program to introduce natural enemies against. S. phillyreae.

C. arcuatus was first recorded in Egypt as apredator of Dialeurodes citri (Mesbah, et al., 1998). It was the most dominating predatory species attacking citrus whitefly $D$. citri immatures in citrus trees at Kafr El-Sheikh 
Governorate (northern Egytp). It constituted $41.9 \%$ of the total number of predators found associated with the pest on citrus trees (Mesbah, 1999).

$C$. arcuatus was also observed predating on the pomegranate whitefly $S$. phillyreae immature stages mainly eggs and rarely on the adults (Mesbah, 2000). The population dynamics of S. phillyreae was decreased after releasing of $C$. arcuatus on apple, Olive, pear and pomegranate trees in different locations in Egypt (Abd-Rabou, 2006). C. arcuatus was correlated with the dominate $S$. phillyreae on pomegranate trees as well as the predator and the pest were appeared together on the pomegranate trees by the first week of August (Mesbah, 2008).

This work aimed to give more light on the biology and feeding capacity of $C$. arcuatus predator when fed on $S$. phillyreae immature stages.

\section{MATERIALS AND METHODS}

This study was carried on pomegranate trees growing at the experimental farm, Faculty of Agriculture, Kafr El-Sheikh University, in 2006 and 2007 seasons.

Samples from the predator adults were collected from the pomegranate trees using the sweep net. A pomegranate sprig having ample amounts of the pomegranate whitefly $S$. phillyreae eggs was introduced into a glass vial $(2 x$ $4 \mathrm{~cm}$ ) filled with water to keep the sprig fresh. The vial was placed into a jar $(9 \times 25 \mathrm{~cm})$. C. arcuatus adults were released on the pomegranate sprig to feed on the host eggs, and to oviposit on the sprig leaves. To avoid the camibalism, pomegranate sprig having the predator's eggs were always been substituted by new ones, having S. phillyreae eggs (Tawfik, et al., 1962 and Mesbah, 2001). The sprig carring the predatory eggs were put into Petri dishes until hatching.

Two experiments were carried out under laboratory conditions $(27.5 \pm$ $2.5{ }^{\circ} \mathrm{C}$ and $65-70 \%$ R.H). The first experiment was conducted to study the duration of immature stages and larval efficiency. The second one, to study the longevity and feeding capacity of the adults.

In the first experiment newly laid eggs $(0-24 \mathrm{~h}$. old $)$ of the predator, $C$. arcuatus $(n=10)$ were placed individually on pomegranate leaves in Petri dishes. Newly hatching larvae were provided with access number of $S$. phillyreae eggs in Petri-dishes $(n=10)$. Adults were provided daily with a new food and maintained until the death of all individuals. Survivorship rate was estimated in both experiments by calculating the proportion of alive predators (Mesbah, 2001).

\section{RSULTS AND DISCUSSION}

\section{Population abundance of $S$. phillyreae immature stages and its related predator $C$. arcuatus:}

Data illustrated in Fig. (1) showed that the coccinellid predator. $C$. arcuatus was appeared by the second week of June (10 individuals/100 stroks) coincided with the first peak of $S$. phillyreae pupae (70 pupae/40 leaves). The first peak of $C$. arcuatus was recorded on July 15 (18 
individuals/100 stroks) coincided with the first one of $S$. phillyreae eggs (47 eggs/40 leaves) and second peak of the pest pupae (108 pupae/40 leaves), the highest peak of the $C$. arcuatus was detected in the end of August 2006 releated with the highest peak of $S$. phillyreae eggs (438 eggs/40 leaves) and third peak of pupae 240 pupae/40 leaves.

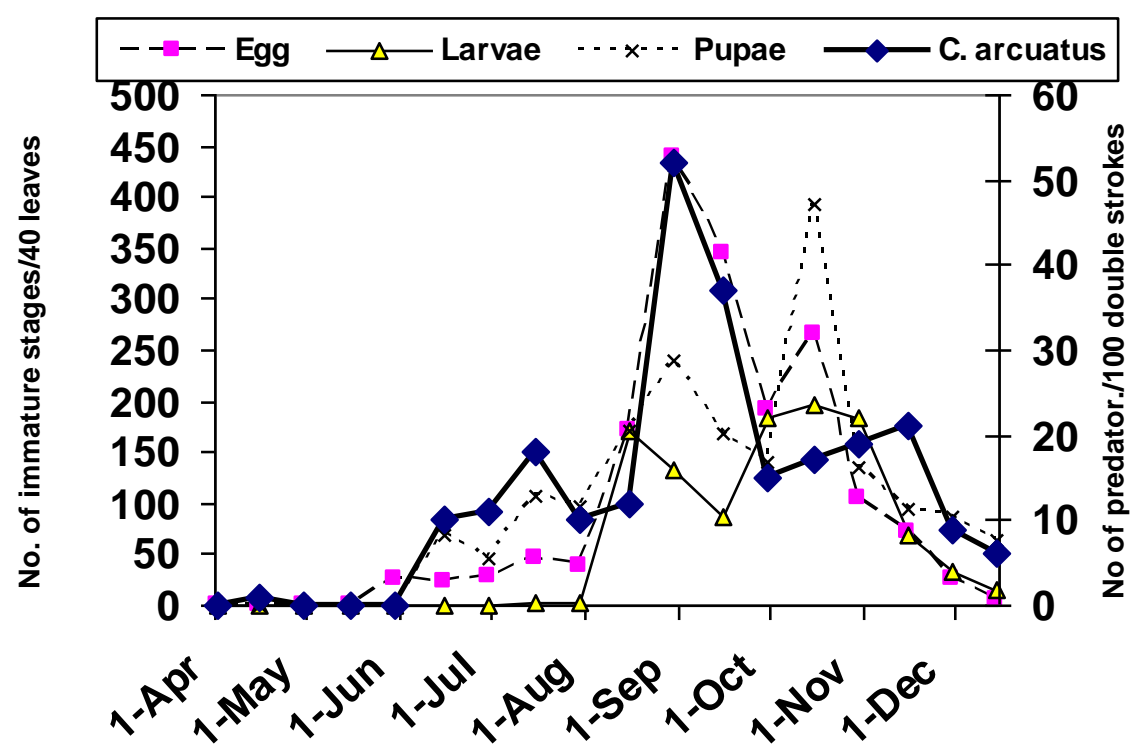

Fig. (1): Population abundance of pomegranate whitefly S. phillyreae immature stages and related predator, $C$. orcuatus adults on pomegranate trees during 2006 season.

In the second season (2007) data illustrated in Fig. (2) indicated that the $S$. phillyreae eggs and $C$. arcuatus were appeared together on 15 June and increased to reach the highest peak on $30^{\text {th }}$ August and represented with 41 individuals/100 stroks and 438 eggs and 353 larvae/40 leaves of $S$. phillyreae. The second peak of the predator was observed on 15 October (36 indi./100 stroks) coincided with peaks of $S$. phillyreae eggs, larvae and pupae 303, 168 and 286,individuals/40 larvae respectively. The present results are agreement with those of Loi (1978), Bathon and Pietrizk (1986) and Gerling (1990) who recorded that $C$. arcuatus was the considerable predator of aleyrodids. In Egypt Mesbah et al. (1998) were recorded C. arcuatus for the first time as a predator of Dialeurodes citri. Also Mesbah (2001) and (2008) recorded that $C$. arcuatus was highly correlated with the dominant whitefly was highly correlated with the dominant whitefly, S. phillyreae immatures on pomegranate trees. 


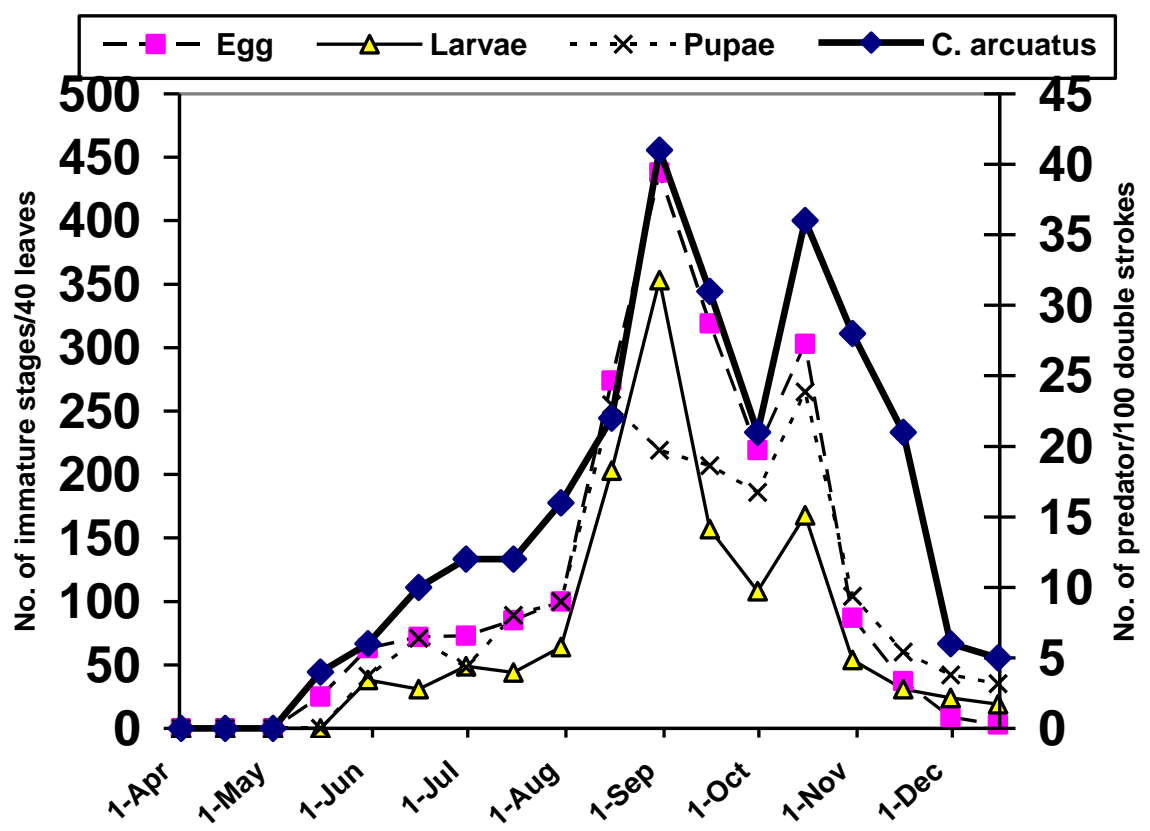

Fig. (2): Population abundance of pomegranate whitefly, S. phillyreae immature stages and related predator, $\boldsymbol{C}$. arcuatus adults on pomegranate trees during 2007 season.

\section{Predator Biology:}

Duration of immature stages:

\section{Egg stage:}

As data shown in Table (1) the incubation period of the C. arcuatus eggs ranged between 3-5 days with an average of 3.6 days. The percentage of eggs hatch ability reached $100 \%$.

\section{Larval stage:}

Larva molts 3 times, the average duration of the four larval instars of C. arcuatus when fed on pomegranate whitefly $S$. phillyreae eggs were 1.2, 2.2, 2.6, 2.8 and 1.1 days of the first, second, third, four in star and prepupae, respectively. Survival rate of larval stage was $92 \%$.

Pupal stage:

The pupal duration ranged between 4-6 with an average 4.3 days. Survival rate of pupal stage was $100 \%$. The total development period ranged between 15-24 days on average 17.8 days.

These result are in line with those of Agekyan (1977) who reported that the total development time ranged between $23-25$ days at $24-27 \mathrm{C}^{0}$. Loi (1978) reported the respective period of 3-8, 8-24 and 3-8 days, for eggs, larva and pupal stage. In both cases the predator was prying on Dialeurodes citri. Bellows et al. (1992) reported that the maximum development period of the predator was at $28.2 \mathrm{C}^{0}$ while the minimum was at $21.1 \mathrm{C}^{0}$ pomegranate 
whitefly was used as prey. Mesbah in (2000) found that total development period averaged 16.79 days when fed on pomegranate whitefly eggs on (14$23 \mathrm{C}^{0}$ ). On the other hand Mesbah (2003) found that the total larval period, pupal stage and total development period averaged 11.83, 6.44 and 22.57 days respectively when fed the $C$. arcuatus on Bemisia tabaci eggs on 14-23 $\mathrm{C}^{0}$.

Table (1): Life cycle and longevity of the predators Clitostethus arcuatus (Rossi) under laboratory conditions $\left(27.5 \pm 2.5 \mathrm{C}^{0}\right.$ and $65-70 \%$ R.H)

\begin{tabular}{|l|c|c|c|c|}
\hline \multirow{2}{*}{ Stage } & \multicolumn{2}{|c|}{ Duration (days) } & \multirow{2}{*}{ Mean } & $\begin{array}{c}\text { Mean numbers } \\
\text { of eggs/Female }\end{array}$ \\
\cline { 2 - 3 } Eggs stage & Minimum & Maximum & & of \\
Egarval stage & & $\mathbf{5}$ & $\mathbf{3 . 6}$ & - \\
$1^{\text {st instar }}$ & 1 & 2 & & \\
$2^{\text {nd }}$ instar & 2 & 3 & 2.2 & \\
$3^{\text {rd }}$ instar & 2 & 3 & 2.6 & \\
$4^{\text {th }}$ instar & 2 & 3 & 2.8 & \\
Prepupae & 1 & 2 & 1.1 & \\
Larval period & 8 & 13 & 9.9 & \\
\hline Pupal stage & 4 & 6 & 4.3 & \\
\hline Total development period & 15 & 24 & 17.8 & \\
\hline Adult longevity & & & & \\
\hline Male & 65 & 71 & 59.2 & \\
\hline Female & 94 & 114 & 103.2 & \\
\hline Pre Oviposition & 8 & 13 & 9.4 & \\
\hline Oviposition & 76 & 93 & 85.4 & 127.2 \\
\hline Post-Oviposition & 6 & 9 & 8.2 & \\
\hline
\end{tabular}

\section{Adult longivety:}

Mean longevity of adult male ranged 65-71 days with on average 69.2 days. Meanwhile the adult female ranged 94-114 days with an average 103.2 days, while the pre-oviposition period ranged 8-13 days with an average 9.4 days, the oviposition period ranged 76-93 days with an average 85.4 days and the post oviposition period ranged between 6-9 days with an average 8.2 days (Table 1 ) this results are in agreement with those of Bathan and Pietrizk (1986) who recorded a longevity of 150 days at 22-24 $C^{0}$, when fed on eggs of Aleyrodes proletella. Bellowes, et al. (1992) reported that the timed mean longevity of Female (98.9 days) was recorded at $21.1 \mathrm{C}^{0}$. Data also agremented with those of Mesbah (2000) who recorded longevity of adults (male and female) averaged of 94.33 and 97.00 days when fed on $S$. phillyreae eggs on 18-22 $\mathrm{C}^{0}$. In contrast, the obtained data do not agree with those of Mesbah (2003) who found the mean longevity of adults male ranged between 176-214 days with an average of 192 days, while the adult female ranged 176-236 days with an average 207.00 days when the predator fed on Bemisia tabaci eggs $\left(14-23 \mathrm{C}^{0}\right)$. 


\section{Predator efficiency:}

C. arcuatus larvae consumed an average of 29.6, 85.0, 101.0 and 104.0 eggs of $S$. phillyreae during the $1^{\text {st }}, 2^{\text {nd }}, 3^{\text {rd }}$ and $4^{\text {th }}$ instars, respectively Table (2). The total consumption number ranged 148-521 eggs with on average 319.8 eggs during its development period. In this regard, Liotta (1981) and Bathan and Pietrzik (1986) recorded that C. arcuatus larva consumed during the course of its development not more than 300 and 544 eggs of $D$. citri and $A$. proletella, respectively. The present data also agreement with these of Mesbah (2000) who found the C. arcuatus larvae consumed on average 325 eggs of $S$. phillyreae during its development period. The present data incontrast with these of Mesbah (2001) who recorded that predator larva consumed an average total number of 987.5 eggs of $B$. tabaci during its development period. As for $C$. arcuatus adult male was consumed on average 4237.6 of $S$. phillyreae eggs, while the adult female consumed an average 5486.6 eggs during its longevity.

Table (2): Number of Siphoninus phillyreae eggs consumed by Clitostethus arcuatus (Rossi) larvae and adult under the laboratory conditions $\left(25.5+2.5 \mathrm{C}^{0}\right.$ and $70-81 \%$ R.H $)$.

\begin{tabular}{|l|c|c|c|}
\hline \multicolumn{1}{|c|}{ Stage } & Range & Mean \pm S.D. & Mean/day \\
\hline Larval stage & & & \\
$1^{\text {st }}$ instar & $14-44$ & 29.60 & 24.66 \\
$2^{\text {nd }}$ instar & $59-112$ & 85.00 & 36.84 \\
$3^{\text {rd }}$ instar & $60-124$ & 101.00 & 45.90 \\
$4^{\text {th }}$ instar & $91-123$ & 104.00 & 47.27 \\
\hline Total & $148-523$ & 319.80 & 44.41 \\
\hline Adult & $3720-4344$ & & \\
Male & $4913-6112$ & 4237.6 & 61.23 \\
Femol & & 5486.6 & 53.16 \\
\hline
\end{tabular}

\section{REFERENCES}

Agekyan, N.G. (1977). Clitostethus arcuatus (Rossi) (Coleoptera, Coccinellidae), a predator of the citrus whitefly in Adzharia. Entomol. Rev., 56(1): 22-23.

Bathon, V.H. and J. Pietrizik (1986). Zur Nahrungsaufnahme des BegenMarienkfers, Clitostethus arcuatus (Rossi) (Col.: Coccinellidae), einem Vertilger der Kohlmottenlaus, Aleurodes proletella linné (Hom.: Aleurodidae). J. Appl. Ent., 102: 321-326.

Bellows, T.S.; T.D. Paine and D. Gerling (1992). Development, survival, longevity, and fecundity of Clitostethus arcuatus (Coleoptera: Coccinellidae) on Siphoninus philyreae (Homoptera: Aleyrodidae) in the laboratory. Environ. Entomol., 21(3): 659-663.

Dreistadt, S.H. and M.L. Flint (1995). Ash whitefly (Homoptera: Aleyrodidae) overwintering and biological control by Encarsia inaron (Hymenoptera: Aphelinidae) in Northern California. Environ. Entomol., 24(2): 459-461.

Gerling, D. (1990). Whiteflies: their bionomics, pest status and management. IntercepLtd., Andover, UK, 348 pp. 
Hafez, M.; MF.S. Tawfik; K.T. Awadallah and A.A. Sarhan (1979). Studies on Eretmocerus mundus Mercet, a parasite of the cotton whitefly, Bemisia tabacii (Genn.) in Egypt. Bull. Soc. Ent. Egypt, 62: 15-22.

Liotta, G. (1981). Osservazioni bio-etologiche su Clitostethus arcuatus (Rossi) (Col.: Coccinellidae) in Sicillia Redia, 64: 173-185.

Loi, G. (1978). Osservatzioni eco-etologiche sul coleottero Coccinellidae scimnino Clitostehus arcuatus (Rossi), predatore die Dialeurodes citri (Ashm.) in Toscana. Frust. Entom., 1: 123-145.

Mentzelos, I.A. (1967). Contribution to the study of the entomophagous insects of Siphoninus phillyreae (Halid) (Aleyrodidae) on pear trees in central Macedonia. Report of the plant protection Agricultural Research Station, Thessaloniki, 3: 92-102.

Mesbah, A.H. (1999). Studies on certain natural enemies of the whiteflies. Ph.D. Thesis, Dept. of Econ. Entomology, Faculty of Agriculture, Kafr El-Sheikh, Tanta University. $133 \mathrm{pp}$.

Mesbah, A.H. (2000). Development and efficiency of Clitostethus arcuatus (Col., Coccinellidae) predator on Siphoninus phillyreae (Hom., Aleurodidae) at Kafr El-Sheikh Governorate, Egypt. Egypt. J. Biol. Pest. Control, 10(2): 123-127.

Mesbah, A.H. (2001). Biology and efficiency of Clitostethus arcuatus (Rossi) (Coleoptera: Coccinellidae) as a predator of Bemisia tabaci (Genn.) (Homoptera: Aleyrodidae). Egypt. J. Biol. Pest Control, 11(2): 95-100.

Mesbah, A.H. (2003). Pomegranate whitefly, Siphoninus phillyreae (Haliday) (Homoptera: Aleyrodidae) population dynamics and parasitism rates on pomegranate trees at Kafr El-Sheikh governorate, Egypt. Egypt. J. Biol. Pest. Control, 13(182): 71-74.

Mesbah, A.H.; A.H. El-Heneidy; S.M. Metwaly; Z. Shenishen and H.A. Boraei (1998). Clitostethus arcuatus (Rossi) (Coleoptera: Coccinellidae), A new recorded predator species, of the citrus whitefly, Dialeurodes citri (Ashm) (Homoptera: Aleyrodidae) in Egypt. Egypt. J. Biol. Pest Control, 8(2): 99-100.

Priore, R. (1969). Dialeurodes citri (Ashm.) (Homoptera, Aleyrodidae) in Camania. Notes on morphology and biology. Boll. Lab. Entomol. Agrar. F. Silvestri Portici, 27: 287-316.

Soylu, O.Z. (1980). Investigations on the biology and control of citrus whitefly (Dialeurodes citri Ashmead) injurious in citrus orchards in the Mediterranean region of Turkey. Bitki Koruma Bul., 20(1-4): 36-53.

Tawfik, M.F.S.; M. Hafez and B. Said (1962). Studies on scymnus (Pullus) syriacus Mars. (Coleoptera: Coccinellidae). Bull Ent. Soc. Egypt. XLVI 485-504.

Ulu, O. (1985). Investigations of the taxonomic characters, damage, biology, ecology and control of the citrus whitefly Dialeurodes citri (Ashm.) (Homoptera: Aleyroididae), which attacks citrus in the Aegean region. Ege Univ. Ziraat Fakultesi Dergisi, 22(3): 159-174. 
Awadalla, S. S. et al.

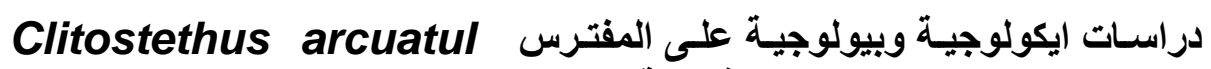

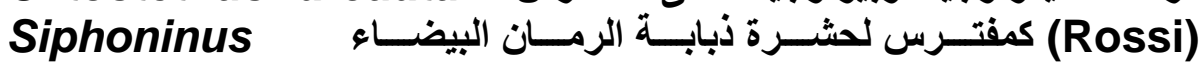

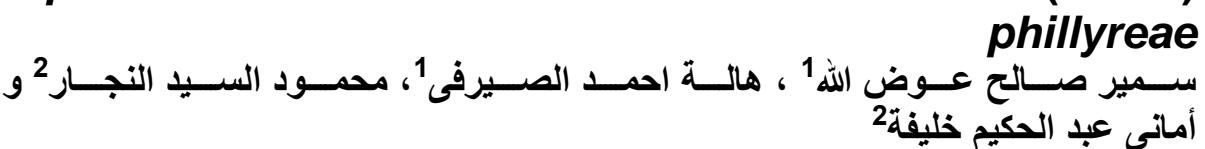

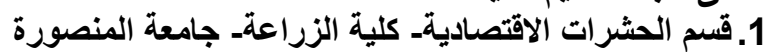

2. معهد بحوث وقاية النباتاتـ مركز البحوث الزراعيةـ الدقى- الجيزة

تم في هذا البحث دراسة الوفرة العددية وكذلك البيولوجي والكفاءة الإفتراسية للمفترس

Clitostethus arcuatus

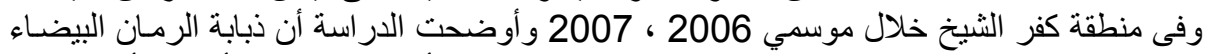

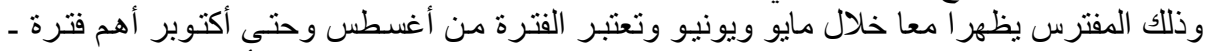

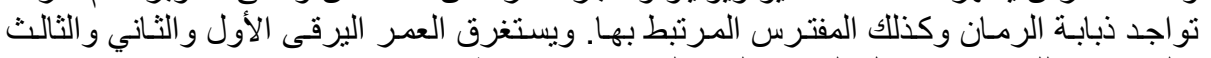

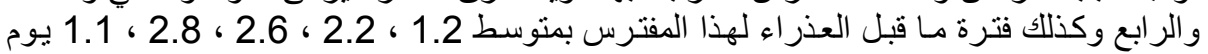

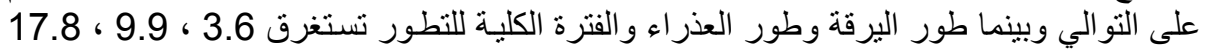

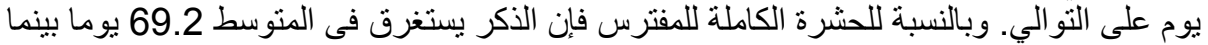

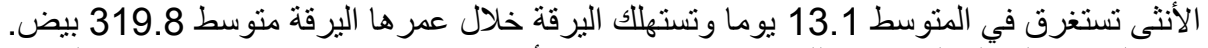
بينما الحشرة الكاملة الذكر يستهلك 4237.6 بيضة والأنثى 5486.6 بيضة من بيض ذباتئة الرمان البيضاء.

قام بتحكيم البحث

كلية الزراعة - جامعة المنصورة كلية الزراعة - جامعة الازهر

أ.د / أعداد حسن عبد السلام

أ.د / حمدى احمد محمد الدلائ 